\title{
The Salvation and Aesthetic Structure in "Sifr Ayoub" for Badr Shakir Al-Sayyab
}

\author{
Linda Abd Al-Rahman Rade Obaid \\ Yarmouk University, Irbid, Jordan \\ Email: Linda_Obead@yahoo.com
}

How to cite this paper: Obaid, L. A. A.-R. R. (2020). The Salvation and Aesthetic Structure in "Sifr Ayoub" for Badr Shakir Al-Sayyab. Advances in Literary Study, 8, 107-118. https://doi.org/10.4236/als.2020.83009

Received: February 27, 2020

Accepted: May 4, 2020

Published: May 7, 2020

Copyright $\odot 2020$ by author(s) and Scientific Research Publishing Inc. This work is licensed under the Creative Commons Attribution International License (CC BY 4.0).

http://creativecommons.org/licenses/by/4.0/

\begin{abstract}
This study deals with the problem of searching for salvation and death in the poem Badr Shaker Al-Sayyab, "Sifr Ayoub", and standing by the aesthetic of artistic construction in saying the poet's visions and his perceptions towards himself and towards existence. He was known for his inclination in his poetry towards the dualities of life and death; at times he became entangled at first despite his suffering, and he resisted the second with the images of life, her love and the possibilities of supplication and begging in search of ways to survive in harmony with his internal psychological defeats on the one hand, and with the ugliness of what is happening in Iraq in the political and social realities on the other hand, to date in his poem "The Book of Job" for the last period of his life, clinging to what he could through the ways of salvation, looking for the emancipation of himself from the torments of the body of the soul, within many contradictions that make him in his interior a certainty of destruction that is ready to kill him. Al-Sayyab relies on various artistic techniques in building his poem in line with the inherited one time, outside it and again, as a pioneer in the poetic modernity movement in the twentieth century. The study adopted an analytical textual approach to approach. It consisted of a preamble, a presentation based on sub-headings dealing with the contents and problematic of the poem, and the conclusion and a list of references and sources.
\end{abstract}

\section{Keywords}

The Salvation, Al-Sayyab, Commensurate, Inventory, Alienation

\section{Introduction}

Badr Shakir Al-Sayyab is a pioneer of modernity in Modern Arab Poetry (AlSayyab, 1997: p. 32). He was able to create poem that is commensurate in both content and shape with the characteristics of the contemporary reality in terms 
of its new social, economical, and political circumstances.

$\mathrm{He}$ is considered one of the poets who renew their artistic poems by depending on modern new techniques to reveal their both opinions and perceptions, to rave their intellectual inventory, to demonstrate their conscious and unconscious emotional suffering as a result of subjective conditions and general conditions that are resulted from the peculiarity of this stage such as the political crisis that is reflected on constituting the contemporary educated society with its crisis and alienation.

In fact, poetry in general and creativity in particular are considered one of the insurgencies on the ugliness and weakness, out of the ordinary, rejecting the values of stability and inertia that is embodied in destroying the traditional format for Arabic poem and generating the activation poem in which Al-Sayyab was one of its pioneers.

Hereinafter referred to as (banan) since its inception. There is no doubt that Al-Sayyab was exposed to both oppression and suffering that was, on the one hand, represented in the political circumstances and in lung disease that admitted him in multiple constituencies. In addition to congenital edema that caused him a special kind of suffering that has been melted in Al-Sayyab poetry by considering him as a habitat for his ideas whether for himself or for himself and for human and universe in general by considering his innovative ability as a mean for achieving it.

Al-Sayyab poetry is devoid of both life and death. To illustrate, he sometimes tends to cling with the former despite of the suffer that might cause and resists the later due to his love of life and the possibilities with an invocation and begging seeking for survival methods. He was suffering from a terminal illness that kept eating him until he was unable to move. However, such ordeal might cause cute psychological fluctuations and tortures which have affected him and has targeted Sayyabian poem.

It is clearly obvious in "Sifr Ayoub" poem the subject of this study. This study will stand by these two forces that have attracted Al-Sayyab in his journey in searching for salvation. Its core is the modern poem with its artistic techniques and aesthetic structure since the form and content get together the poet's view towards life and death as a whole. He dated such period of his life clinging as much as possible with salvation means. In addition, he wanted to dispose himself from the agony in his soul in various contradictions in which he realized the destruction that might occur him.

\section{Previous Studies}

There is no study specialized in the idea of searching for salvation and death in the poem of Job of Badr Shaker Al-Sayyab, but was dealt with in the course of talking about renewal in Al-Sayyab as a pioneer of poetic modernity, as well as the poem or parts of it were studied in the study of various topics I mention but not limited to: 
- Symbols of the symbol in Al-Sayyab's poetry by Layla Sara, which is a Master's thesis published at the University of Moulay El-Taher.

- The sexual intercourse in the contemporary poem of Bou Aisha Bou Amara in the Capital Magazine of India 2016.

- The possibilities of transformation in the poem sifer Ayoub by Nasser Shaker Al-Asadi in the Arab Gulf Magazine 2013.

- Narration of narration and poetry in the contemporary poetic discourse of Ziane Ashour.

- The effect of life and death on building the poem in the poetry of Al-Sailab by Abd Al-Basit Murshideh.

\section{The Importance of Studying}

The importance of this study comes as it deals with a new topic that no one has touched on studying independently, but the discussion came in the folds of studies dealing with other topics related to the poem, or when dealing with the general contents of the poem, or when examining the topic of renewal in AlSayyab's poetry in general as one of the pioneers of renewal in The modern poem.

The importance of the topic stems from the fact that it touches an important existential aspect in Al-Sayyab's life, and constitutes an important part of the formation of Al-Sayyab's ideas and beliefs, and his psychological formation that is reflected in his poetry, due to the troubles and sufferings that disturb him.

In addition to the fact that the idea of death and life is a concern in its various formations, it constitutes the tragic fate of man in general, who occupied all artists and creators of different affiliations and beliefs.

\section{Analysis}

Al-Sayyab poem "Sifr Ayoub" is consisted of ten parts that are moving from two big structures in which one of them dominate the other, namely death structure that dominates poem's language and structure. Life's structure in which the poet seeks for salvation by begging and clinging by the methods of accessing them in terms of peace and tranquility.

Analysis will be concentrated on the first five parts. Each one of them represents indicative unit in which each one of them immerse in one structure inside the body of the poem that has harmonious rhythm and content in accordance with death view and salvation that organize the poem because the poet is sick and concern about his destiny that represents the concern of the existential human as a whole which leads him to search for both salvation and its methods within emotional cases that varies from despair, pain, hope, and Sufi manifestations in searching for a light that drive him to embrace salvation. Most importantly, Al-Sayyab depends on various technical techniques in creating his poem that is either consistent or inconsistent with the inherited.

It is commonly known that Al-Sayyab is considered the best one in employing 
legends, religious stories with its surveyed and Islamic reference in modern poem after he was one of the pioneers who wrote activation poem (free poetry) (Al-Attiyah, 1986: p. 34).

Al-Sayyab is regarded as the best poet in using Al-Qena (mask, it is a metonymy for a mysterious person) which stands for an artistic method used by poets to express their experiences indirectly and by technical mean, symbol, substantial equivalence, the dependence on the object pronoun, monologue, dialogue, interviews, and structural methods that surpass on predictive sentence, predictability and recovery technique by the presence of rich linguistic glossary that contains high linguistic outcome, extensive cultural acknowledgement, and remarkable referential richness (Al-Attiyah, 1986: p. 32).

"Al-Qena (mask) poem contains symbol in its various structures and internal tensions. The symbol has a significant presence and existence in its plot, textual and indicative contexts, the relation between Al-Qena (mask) and symbol is a correlation between a part with whole and private with general. Al-Qena (mask) is a private and delicate from symbol parts it has its own characteristics and presence that distinguish it from other types or symbolic patterns and the context of Al-Muqana (a person who does not reveal his emotions or personality like wearing mask) text is considered as a bowl for the integration of poet's personality and its interaction with heritage personality. The symbol constitutes the string that connects this interaction and its entanglements in the new text" (Al-Musa, 2007: p. 34).

There is no Arabian poet used Al-Qena (mask) as the manner in which AlSayyab used it as well as his dependence on legendary, religious stories, heritage. He was the first one who has taken the form of unification with its symbol. $\mathrm{He}$ recorded the first steps towards the formation of Al-Qena (mask) (Bin, 2007: p. 13) to make the poet's nature completely identified with his conviction to reveal what he wants.

The poem named "The Crucifixion of Jesus" is considered among the first poems that is based on this technique (Kennedy, 2003: p. 185). Possibly Al-Sayyab tendency is attributed to his suffering that has led him to have violent physical and psychological upheavals that has affected him.

Al-Sayyab has pretended the personality of "Ayoub Abd Al-Salam" in "Sifr Ayoub" poem and Al-Sendbad in "Day Trips" poem. In fact, such personalities clarify the sufficient capacity to inspire his personal suffering, to hide himself behind it, and to reveal what he needs to say because of the fear of political oppression.

The poem of "Sifr Ayoub" expresses the poet's pain and agony once he appears that he believes in the proximity of his black death that is represented in death and align with his internal fears as he considered one of those people who believed in divine religions such as the torture that comes after the death, the punishment for sins and mistakes since he has acknowledged the philosophy of the universe and existence that is derived from people's experiences and perspectives. All of which enable him to realize the concern of death, the magnifying 
of its image until the violence of its sentiment which prompted him to cling with (Shuqairat, 1987: p. 145) the life's aspects and beg with the miracles to survive. On the other hand, he is inclined to death concept because he believes that both awareness and speaking of death clearly. It does not reflect a dark moody it is merely as a raven croak instead it represents a progress in consciousness, logical thinking. If this perception was common among philosophers and constitutes a specific perception for time. As such, for present and future (Nasrallah, 2006: p. 221) that is embodied in a form of ideas and abstract theories addressing the worried wandering brain. For artist the poetry is considered as: "images and artistic formations that melts in the consciousness of the recipient after it has been considered as a squeezer for his soul and for tackling human suffering it consists of dramatic coordination and artistic image. Therefore, poetry is considered as existential process that is embodied in poet's awareness in creating self-component for poet" (Manaf, 2012: p. 79).

Sifr Ayoub poems represents a conflict situation between life and death and passing by the possibilities for transforming and pegging seeking for salvation in which all the details as well as possible and impossible scenarios are searching for its existence. In certain cases he clings to the mean of salvation, but in vain while in some cases he looks for another mean within absurd circle that drives him into an inevitable destiny resulted from severe illness that impedes all the means of Salvation.

\section{Salvation Methods in Job's Poem}

\subsection{God}

In reference with the salvation means that are existed particularly at the beginning of Al-Sayyab poem that he clings to beg God who constantly thank him even for his illness trying as much as possible to be satisfied for his calamity because he wanted as much as possible to approximate himself with Al-Qena (mask) rendered in his poem. Ayoub peace be upon him story (to enable him to draw a similar conclusion regarding his escape from death despite of his calamities that is commonly known as (Sifr Ayoub) in which the poet considered it as a textual beginning for his poem. All of which made the poem as a human saga for physical and psychological torture which prompted the self of the poet to either beg or cling within an interconnected case from possibilities and no possibilities.

In this regard, God almighty said: "and remember Our servant Ayyub, when he called upon his Lord: The Shaitan has afflicted me with toil and torment (41) Urge with your foot; here is a cool washing-place and a drink (42) And We gave him his family and the like of them with them, as a mercy from Us, and as a reminder to those possessed of understanding" (The Holy Quran, $631 \mathrm{AD}$ ).

In the old testimony, the story justifies the poet independence in eliciting the idea of his poem (Fikri, 2013: p. 6).

Al-Sayyab is not sufficient by employing his personal symbols, but he shares the experience without dealing with it external separated things from him. He 
interacted lively by dealing, getting away, and getting close with it. In general, he regards himself as a hero moves between intimate species whether by his physical entity, financial reality by his unique experience (Nasrallah, 2006: p. 84).

He said: "thanks God even if the affliction has prolonged, the pain has dominated, thanks God for your blessing since the calamities are from your generosity" (Al-Sayaab, 1997).

Al-Sayaab started to get close to God more when his death was inevitable due to his severe illness. He believes that his closeness to God is one of the most effective means to get rid of his scourge when there was no mean for escaping. Ehsan Abbas believes that Al-Sayyab death gave an optimal form for the relation between human and Goddess (Abbas, 1978: p. 378).

Even if this relation was apparent, it is considered as a shelter for Al-Sayyan and as a solution for his expatriation resulted from his terminal illness. Death might be considered for Al-Sayyab as an adorable thing. He converted to a contemporary Ayoub in which the voice of illness, death, and satisfaction becomes prominent at the same time (Abdo, 1998: p. 47). The satisfied poet with God's destiny and reincarnated the character of Ayoub tries to defeat death by God's higher force. All of which was seeking to achieve it during his last days. He enjoyed his pain, agony, and late nights as a monk worships God. He believed that both pain and death are merely gifts from God. The pain is considered as a divine touch. The poet exaggerated his description by immersing in meditation circles, he touched the darkness in order to look for revelation and lightness which resembles Sufi imagination.

You are looking at me envying me because of the God's blessings...if the flame of the fire has touched my forehead, you will think it is a kiss from a flame of love. The night is beautiful because it cares of you until the stars disappear and my house window touches your shining light (Al-Sayyab, 1997: p. 249).

Begging and getting close to God by thanking and satisfying with his blessings and accepting Ayoub's agony-Peace be Upon Him-except the first poet's mean to cling with life and looking for salvation in spite of his harvest towards the impossible. The poet here lives in the time of miracle and waiting it the wait of the person who is ascertain from its occurrence after he was hopeless from the remedy, medicine, and cure. The only thing that was available for him is waiting the impossible (Bin, 2007: p. 189).

Al-Sayyab sought in the poem of first salvation to approximate between himself and the thirsty land who God gave it the rain. As such, it becomes thankful whether if the gloom or not. He believed in God's destiny who grants night and magic within a silent pray that beg him to ease his pain that was increasing since months. He added "these wounds are tearing me apart (Al-Sayyab, 1997: p. 97)".

The poet reveals the reason behind his selection for Ayoub Al-Qena (mask) that is attributed to his suffering and his attachment to the cure miracle in spite of his realization to the end of miracles. In spite of his sobering realization to the end of the time of miracles, he considers Ayoub as an objective corollary. They 
unified in one soul. The poet yells and saying.

"If Ayoub Yells then this will be the call. Thank God who wrote our destiny and wrote after that the recovery" (Al-Sayyab, 1997: p. 98).

\subsection{Absent Space}

The second survival mean comes by remembering our destiny that is represented in the warm place whereas his home, Jaykur, children, and house. Although he suffered in the past from hunger, poverty, and coldness, but he was able to tolerate that. All of which will make the universe is open and the light is high and represented in stars. He moves from this nostalgia that made him clings to life more begging for overcoming death. Then he made indirect comparison to his reality abroad describing the coldness, loneliness, and disease which made him unable to resist.

Without illness I would fight hunger, coldness, and darkness. Without you, I feel that I am lost in the crowd (Al-Sayyab, 1997: p. 99). The expatriation is psychological which lead to being away from Jaykur and the family. The people in their new reality alien passers. Do not have intimacy. Bashlar stated that the intimacy of the place comes with the memories and dreams (Bachelard, 1984: p. 37) that have.

He indicated that:

Away from you in Jaykur, without my house and my children in which granite, asphalt, and boredom are pulling me (Al-Sayyab, 1997: p. 25).

Regardless the poverty and hunger in my home, but it is considered as the mean for self to observe its salvation, to survive from illness. The past for Al-Sayyab is regarded as a safe haven that nobody can break it into. It is unlike his painful present (Shuqairat, 1987: p. 123).

The expatriation is a general human phenomenon....it occurred to Al-Sayyab due to his weakness, psychological fluctuations, self and poetry duplication were considered as the core reason for his expatriation. In addition to physical, social, and political reasons (Shuqairat, 1987: p. 164).

In spite of the poet's illness, he revives the pain of expatriation and remoteness from Jaykur. It is demonstrated in poetic comparison between the features of life in his absence universe and the details of expatriation despite of its aesthetics that are converted according to Al-Sayyab psychological status into features devoid of life.

He says: there is no bird in the branches except fragments of steel that fall without fearing from rain, there are no flowers except behind glass façade...they lead to cemetery, jail, and hospitals (Al-Sayyab, 1997: p. 226).

\subsection{Flowers}

Regardless the beauty of flowers, but they turn into a dead specie behind a lifeless glass. They are only used for cemeteries, jails, and hospitals visits because it 
might implicit for expatriates a closed place like jail, causing death and illness as indicated in his rendering to both hospitals and cemeteries which represent death concerns that pressing on the poet who tries to get rid of them.

The poet feels the inability to survive from death to cling to third aspect from salvation. He calls the florist who represents the aspects of beauty, love, and life. $\mathrm{He}$ is begging him and asking for an alive flower that resembles his country's flowers that awaken his internal feeling concerning the ability to survive by the dominance of his pain and expatriation.

O the florist

Do you have a lively flower?

Do you have a flower that evokes the feeling of love?

Do you have a watered red flower?

Oh there is a tropical sun (Al-Sayyab, 1997: p. 254).

Whenever he realizes the futility of appeal his face becomes angry until yelling:

Shall I scream in the deaf streets of London: give me my lovers?

In case if screaming who will listen to my suicidal yelling (Al-Sayyab, 1997: p. 256).

Screaming is absurdity, calling in the deaf space does not have memories. Within nostalgia and longing for lovers in the country makes Al-Sayyab a suicide soul. The more he clings to salvation means, the more his realization to the impossibility of survival and his pain exacerbate.

Al-Sayyab realizes that nothing will return. Therefore, he begs God due to his force that will rescue him as Ayoub. He complains about his expatriate, poverty, loneliness, coldness. He invokes God in the middle of the night, from the darkness of death, he has been exhausted from his illness and pain and wanted to get rid of it, survive, and return home in a verse in which Al-Sayyab and Ayoub unified into one person who enjoys an end that resembles his religious symbol/Ayoub.

\subsection{The Symbol of Absolute Evil/Cain}

The salvation methods in "Sifr Ayoub" his inclination towards the absolute human who begs God for salvation in spite of the wickedness implications, which has led Al-Sayyab to lose his faith with people by his calling to Cain:

My brother O You O Cain

Take my hand from sickness

I mean ease my pains and take away my sorrows (Al-Sayyab, 1997: p. 255).

The clinging is here is to cemetery to make death as a mean of survival from death:

"Who except you shall I pray among the stone cemeteries" (Al-Sayyab, 1997: p. 255).

Al-Sayyab selection to Cain from the evil he represents since the beginning of the humanity and calling him as a brother is just for atoning the evils of people. Thus, he has been symbolized as Cain and the victim Abel. His illness was mere- 
ly considered as atoning from the sins of people (Bin, 2007: p. 107). It has been mentioned in more than one poem of Al-Sayyab.

The means of salvation are accelerating from the general to the specific. $\mathrm{He}$ begs the lord of Ayoub to bring him to life that is represented in his wife, children, and home because he was pained for their absence. He drew a picture for children running among the palms in Iraq. As he was drawing the spectacle of the life in his country which he misses. Rendering the photo of his wife who waits his return, but he was walking towards her without cane. He escaped death by returning to his country in spite of the political, economical, and social suffering. In fact, his nostalgia to his past is only his nostalgia to survive.

O Lord Return Ayoub to me

Jaykur, sun, and children running among palms (Al-Sayyab, 1997: p. 250).

\subsection{Death}

Al-Sayyab feeling towards death exacerbate in spite of his clinging to the various means of salvation because of his fear of the western cemetery. All of which prompted him to wait for the miracle in order to inhale the sun of his country, the smell of its mud. He was begging for salvation from these feelings even if his death is the solution provided being in his home. For him dying is less painful than being here.

He said: "I wish if there is a grave here (Al-Sayyab, 1997: p. 250)".

Begging for dying and choosing a cemetery seems impossible because he is residing in London for taking remedy. The death is getting close to him away from his country.

Al-Sayyab torture circles and his concern from hunger, poverty, and disease. Also, his despair and his worrying for the family only emerge from the humiliation need in which his death dominates his ability. Then he becomes unable for either resist or change. As such, Al-Sayyab invokes the coldness of alienation although there is no intimacy between them.

The utmost despair was his begging for the ruthless life details that looks like death. He waits for sympathy and mercy in the absence of the lively possibilities.

"O snow....Your mercy I am strange

I have a house in my beloved Iraq

My lover there on the stone (Al-Sayyab, 1997: p. 262)".

\subsection{The Miracle}

Al-Sayyab still considers Yaqoub as a bridge and a miracle for salvation. $\mathrm{He}$ tracks the occurrence of miracle hoping for getting rid of salvation. He wishes if he is the Lazarus to have the power to revive these bones when they have rotted away. Clinging to supernatural miracles is the only method for disposing of his inevitable destiny who is waiting it fearfully.

I wish if prophets' destiny has not been ended

I wish if I am the Lazarus to take the doves out from him 
From the darkness of death

Al-Sayyab depended on religious symbols is only a mean for begging God and realizing that survival only occurs by extraordinary force.

\subsection{Women}

Calling and monologue woman is considered as a mean of salvation because she represents and motivates life, and memories partner in the country. He might render the name of (Iqbal) to denote his need for life to demand on him in order to take him out from despair and death:

I will come back do not give up my return

A phone before knocking the door has returned

Lazarus from the country of darkness and tears

Kiss me on a head in which death has destroyed it

Stare on the eyes which witnessed torture and despair (Al-Sayyab, 1997: p. 294).

Al-Sayyab justifies for himself his return and he sees in a woman a rescue in which her kiss removes his sickness. If he survives from illness, he will not his house and home whatever happened.

Even if Al-Sayyab conceives internally that death his inevitable destiny, but the flame of life and love is represented by his home, wife, children, and woman. Generally speaking, he was not completely despair. Sometimes he begs God to rescue him by his miracles within internal fluctuations and conflicts as the theosophist who stuck in manifestation and appearance. The poem moves from the imperatives and possibilities victorious over the imperatives that overcome all the means of salvation.

\section{Technical Techniques}

The time for Ayoub goes so slowly that commensurate with the poet's inability, sickness, and despair. Two opposite movements attract him, one towards the past despite of its poverty and hunger. However, it was considered a beautiful time for its relation with the first poet that is represented in home whereas lovers and memories. On the other hand, the present time is painful connected with closed spatial space that is alien as well as there is no intimacy except passers, illness, and suffering.

He said: "in London the night as a death a cold and boredom night the night is beautiful: the resonance of day, the car horns from distance and the groans of patients (Al-Sayyab, 1997: p. 294)".

If we try to explore the terms of the poem we will find it moves between three interconnected circles like despair and grief terms that imply an inevitable death he monitors to present the time of disappearance, such as: calamities, darkness, dominated, purpose, his pains, destruction, flame, night, interruptions, agonies, echoes of owl, the forests of night, clouds, granite claws, asphalt, the eyes of pain, loneliness, the darkness of the night, beasts, coldness. 
On the other hand, he employs the terms that denote pain, cling to life, and salvation. It is worth mentioning that such terms have the least percentage comparing with the number of words in the poem which represents the stage of suffering seeking visibility, light, and salvation. For example: "thank God, gifts, donation, charm, rain, beautiful, light shining, moon, recovery, life, house, my children, flowers, lively floors, love, passion, I will forget, I will heal...”.

In addition, this circle leads him return to disappearance without embracing or salvation to immerse in the inability glossary. For instance: "wasting, yelling silently, darkness, London deaf streets, graves, separated, lost, middle-aged, paralyze my movements, the whirlpool of destiny, a suicidal yelling, burdens, lost, orphans, blood, cold night, the night and its darkness, Cain, death, calamity, pains, alienation, the extreme darkness, my bones are trembling...".

The death in "Sifr Ayoub" poem is an inherited phenomenon that obsesses the inner feelings of poet. To clarify, he tries as much as possible to seek for salvation and emancipation means from his spatial and temporal space that manifests the life aspects. In order to revive a slow time and he seems unable to do anything just begging miracles for escaping from his inevitable destiny and dating the bereavement of human in general and the bereavement of self in particular and waiting for his death.

\section{Conclusion}

- Badr Shaker Al-Sayyab was able to create poems that are compatible in form and content with the privacy of contemporary reality, with his new political, social and economic circumstances. He is one of those who renewed the structure of their poems by relying on modernist techniques.

- Al-Sayyab tends in his poetry about the dualities of life and death; sometimes it becomes entangled in the first despite its suffering, and resists the second with the images of life, her love, the possibilities of supplication, and the plea in search of ways to survive.

- The poem Al-Sayyab "Sifar Ayoub" consists of ten parts that move within two large structures, one dominating one over the other: the death structure that overlooks its ten districts, and two aspects of the poem's language and perceptions, and the structure of life that the poet tries to be saved by begging, and adhering to the methods of reaching it where peace and tranquility are achieved.

- Each part of the poem constitutes a semantic unit that dissolves each in one structure within the body of the poem harmoniously rhythmically and securely according to the vision of the duality of death and the search for salvation that organizes the whole poem.

- Al-Sayyab used in the poem "The Book of Job" various technical techniques, such as the technique of mask, the objective equivalent, in addition to leaning on the conscience of the speaker, intimacy, dialogue, interviews, and construction methods that overwhelm the news camel, retrieval technology, forward-looking, and many others, In the presence of a rich linguistic dictionary 
accessible from a high linguistic outcome.

- The "Sifar Ayoub" represents the state of conflict between death and life, and the passage of possibilities of transformation and promotion in search of salvation, which searches for its existence in all the details and possible possibilities.

- And it is not possible around him, while holding on to one of the means of salvation and does not help, we see him going to search for another within a futile circle that leads to his inevitable fate resulting from a severe disease that stands in the way of all the methods of salvation.

- Al-Sayyab recited various and different ways in his poem in his attempt to search for salvation and release from torment, ending with his choice of death as one of the ways of salvation.

- The poem moves between two times, within two opposing movements: a past time that overlooks a slow and heavy weight, but it is a beautiful time because it is related to the space of the first poet represented in the homeland, where loved ones and memories, and a painful heavy present time associated with a closed closed spatial space with no familiarity with it, and only transients and disease, and suffering.

\section{Conflicts of Interest}

The author declares no conflicts of interest regarding the publication of this paper.

\section{References}

Abbas, I. (1978). Badr Shaker Al-Sayyab, a Study of His Life and Poetry (4th ed.). Beirut: Dar althaqafat.

Abdo, T. (1998). The Poet and Death, Al-Resala Magazine, No. 1098. Cairo.

Al-Attiyah, K. (1986). The Linguistic Synthesis of Al-Sayyab Poetry. Baghdad: Dar Alshuwuwn Althaqafiat.

Al-Musa, K. (2007). The Structure of the Mask in the Arabic Poem Binyat Alqunae fi Alqasidat Alearabia. The Literary Situation Magazine, No. 366. The Literary Situation, Damascus: Writers Union.

Al-Sayyab, B. S. (1997). Al-Diwan. Beirut: Dar Al-Awda.

Bachelard, G. (1984). Aestheticism of the Place, Translated by Ghalib Helsa. Beirut: University Foundation for Studies and Publishing.

Bin, T. (2007). The Symbol in Arabic Poetry(2nd ed.). Benghazi: Dar Alkitab Alwataniat.

Fikri, P. A. (2013) Who Explained the Bible on the World Wide Web/Tafsseer-seferAyoob./st-tak.org.

Kennedy, M. A. (2003). Symbol and Mask in Arabic Poetry. Beirut: Dar Al-Kitab.

Manaf, A. (2012). The Update in the Poetic Text. Oman: Dar Al-Radwan.

Nasrallah, H. (2006). The Symbolic Towers. Amman: Dar Jadar.

Shuqairat, A. (1987). Alienation in the Poetry of Badr Shaker Al-Sayyab. Amman: Dar Ammar.

The Holy Quran (631 AD). 